\title{
Artes Plásticas e Poesia no Brasil nos Anos 70*
}

\author{
Viviana Bosi \\ Universidade de São Paulo
}

\begin{abstract}
RESUMO: NOSSO PROPÓSITO É DISCUTIR AS RELAÇÕES ENTRE ARTES PLÁSTICAS E POESIA NOS ANOS 70 E VERIFICAR COMO OS DESDOBRAMENTOS DAS MANIFESTAÇÕES DA ÉPOCA CONTINUAM OU NÃO A VALER HOJE COMO FONTE DE INSPIRAÇÃO. AO COMPARAR AS REFLEXÕES QUE ACOMPANHARAM A TRAJETÓRIA DE ALGUNS ARTISTAS PLÁSTICOS E POETAS AO LONGO DAQUELE PERÍODO, PARECE-NOS EVIDENTE QUE PONTOS CRUCIAIS DE TRANSFORMAÇÃO TORNAM SEUS PERCURSOS ATÉ CERTO PONTO PARALELOS. A RADICALIDADE DA ANTIARTE TORNOU-SE UM DESAFIO, QUE REPERCUTE COMO MARCA DE UMA CRISE PROFUNDA QUE LEVA TANTO A IMPASSES COMO A QUESTÕES NÃO RESOLVIDAS QUANTO AO QUE É A ARTE CONTEMPORÂNEA.
\end{abstract}

ABSTRACT: OUR PURPOSE IS TO DISCUSS THE RELATIONSHIP BETWEEN ART AND POETRY IN THE SEVENTIES. WE WISH TO VERIFY IF SOME OF THOSE PERIOD'S ARTISTIC MANIFESTATIONS ARE STILL VALID AS A SOURCE OF INSPIRATION TODAY. COMPARING THE REFLECTIONS ABOUT THE DEVELOPMENT OF A FEW ARTISTS AND POETS DURING THAT PERIOD, IT SEEMS QUITE EVIDENT THAT CRUCIAL TRANSFORMATION ISSUES MAKE THEIR TRACKS PARALLEL TO SOME EXTENSION. ANTIART RADICALISM HAS BECOME A CHALLENGE THAT HAS REPERCUSSIONS IN A DEEP CRISIS THAT LEADS EITHER TO IMPASSES OR TO STILL UNRESOLVED QUESTIONS ABOUT WHAT IS CONTEMPORARY ART.

PALAVRAS-CHAVE: ARTE CONTEMPORÂNEA, POESIA BRASILEIRA CONTEMPORÂNEA, ANOS 70

KEYWORDS: CONTEMPORARY ART, CONTEMPORARY BRAZILIAN POETRY, THE SEVENTIES

\footnotetext{
* Este texto foi apresentado no VI Congresso Nacional da Associação de Literatura Comparada, ocorrido no Centro de Estudos Humanísticos da Universidade do Minho (Braga, Portugal) em 2008. Consta dos anais do evento, que podem ser acessados através do site http://ceh.ilch.uminho.pt.
} 
ma geração é definivel mais pelos problemas que encontra do que por uma maneira comum de resolver seus problemas.

\section{João Cabral de Melo Neto}

Chamou-nos a atenção, em 2007, o debate travado nos jornais entre artistas plásticos e críticos de arte à volta da exposição de uma escultora relativamente recente, Laura Vinci. ${ }^{2} \mathrm{Na}$ verdade, estava em jogo, na discussão que ora passamos a comentar, a concepção de arte por trás da instalação denominada "Ainda viva" que ela então apresentava numa galeria prestigiosa de São Paulo.

Argumentos empregados nas décadas de 60 e 70 contra (ou a favor de) uma transformação na arte voltavam à baila, atualizados, retomando teorizações de Mário Pedrosa (crítico de arte), Hélio Oiticica e Lygia Clark (artistas plásticos), de Ferreira Gullar (poeta e crítico de arte). Era como se algumas das controvérsias inflamadas daqueles anos ressurgissem para assombrar público e especialistas, seja como impasses, seja como questões em aberto.

Laura Vinci, a escultora que suscitava tais discussões, estava expondo um grande retângulo de mármore branco que lembrava um túmulo ou uma mesa, sobre a qual, ou caídas em volta, quedavam centenas de maçãs, arranjadas numa "bela desordem". Do teto pendia ainda uma forma que parecia um candelabro alongando-se até o chão, feito de folhas transparentes de um vidro muito leve.

Alguns críticos indignaram-se com a efemeridade do "objeto" exposto, pressupondo-se que, poucos dias após a inauguração, as maçãs iriam inexoravelmente apodrecer e a instalação não perduraria além dos quarenta dias de duração do evento.

Ferreira Gullar, por exemplo, numa entrevista, quando perguntado se continuava a acompanhar a arte contemporânea, respondeu sarcasticamente, alu-

1 "A geração de 45", II, Obra completa (Rio de Janeiro: Ed. Aguilar, 1994), p. 744. O tema escolhido, sugestivamente amplo, pede recorte. Pretendemos nos concentrar numa única linha de desenvolvimento, sem desdobrá-la em todas as suas dimensões. Estamos cientes de que outras linhagens artísticas se firmavam no mesmo período, as quais não serão aqui abordadas. Por isso a epígrafe acima.

2 Laura Vinci vem trabalhando como escultora há vinte anos, tendo apresentado suas obras em muitas exposições nacionais e internacionais de importância (Bienal Internacional de São Paulo, Centro Cultural Banco do Brasil, MAM-RJ e MAM-SP, e em outros países tais como a Itália, os EUA e Portugal). Realizou cenário e figurino para o Teatro Oficina de José Celso Martinez Correa. Utiliza materiais que evocam "estados fugidios", como a areia e o vapor, em "permanente fluxo", de forma a aludir ao movimento do tempo (confome notou Luisa Duarte, no texto crítico "O murmúrio de um segredo", 2008, publicizado no site da Galeria Nara Roessler). Neste site podem ser visualizados alguns dos seus trabalhos. 
dindo à famigerada instalação como exemplo da degeneração que estaríamos testemunhando:

Não vou mais à bienal, não é mais vanguarda há anos, é a repetição da repetição da mesma coisa. Ninguém pode me dizer que cocô dentro de uma lata é arte. Li que numa instalação uma moça pôs várias maçãs numa mesa. Prefiro as maçãs de Cézanne, que duram mais. Ela vai fazer o quê após desfazer a mesa? Comer, guardar? Apodrece. Quero ver quando ela tiver 70 anos. Tudo o que fez se apagou. Só restarão fotos das obras. Será que não percebe que é uma furada, um oportunismo de momento. (entrevista a Mauro Ventura para o jornal O Globo, 18/11/2007).

O título "Ainda viva" da exposição de Laura Vinci invertia a expressão "still life", da qual "natureza-morta" é a tradução consagrada em língua portuguesa, talvez parafraseando a discussão sobre a não perenidade da obra levada a cabo durante as décadas passadas, como ela mesma assinalou, em sua réplica de defesa:

A única coisa que Gullar sabe sobre o trabalho é que nele existem "300 maçãs” expostas ao apodrecimento, o que lhe pareceu suficiente para tecer considerações ácidas sobre a obra e o estado geral da arte.

Imagino então se ele soubesse que não são 300, mas 7.000 maçãs. Se ele visse que mesmo assim, numa dimensão de Ceasa, uma maçã é uma maçã que sempre lembrará Cézanne.

Que postas numa superfície de mármore, que tem a dignidade do altar, da lápide e da tela branca, elas estão ali falando da tradição da natureza-morta na pintura. Que elas apodrecem em conjunto sem perder a beleza e exalando um perfume embriagante. Talvez ele se lembrasse que "natureza-morta" se diz em inglês "still life", vida parada, ou ainda vida. Que isso é uma pergunta sobre o destino da arte, e não uma confusão da arte com o lixo. Talvez ele se lembrasse que é poeta. ("A maior violência contra a arte é querer falar dela sem ela", Folha de S. Paulo, 28/11/2007).

Ora, alguém poderia, maliciosamente, lembrar o poeta de que uma boa epígrafe para a exposição seria, como amostra dentre tantos outros versos nos quais Gullar trata de frutas apodrecendo, o poema "Desastre" (Barulhos, 1980-1987): 
Há quem pretenda

que seu poema seja

mármore

ou cristal - o meu

o queria pêssego

pera

banana apodrecendo num prato

e se possível

numa varanda

onde pessoas trabalhem e falem

e donde se ouça

o barulho da rua.

Ah quem me dera

o poema podre!

a polpa fendida

exposto

o avesso da voz

minando

no prato

o licor a química

das sílabas

o desintegrando-se cadáver

das metáforas

um poema

como um desastre em curso.

Se tais versos expressam um desejo real, eis que a instalação "Ainda viva" decerto o realiza plenamente. Em vários poemas anteriores, especialmente ao longo dos anos 70, Gullar já tematizara a insatisfação com um tipo de obra de arte imóvel, que lembrasse "pássaro empalhado múmia/de flor/dentro do livro" ("Arte poética", Na vertigem do dia, 1975-1980), defendendo uma poesia que suportasse o cerceamento da temporalidade sem ilusões de transcendência. "A poesia é o presente", assegurava o eu-lírico em "No corpo" (Dentro da noite velor, 1962-1975), quando recusava ao poema o estatuto de mera "emotion recollected in tranquility": "Poesia - deter a vida com palavras?/ 
Não - libertá-la,/fazê-la voz e fogo em nossa voz. Po-/esia - falar/o dia ("A poesia", idem), que ecoava, insistente, os sentidos do corpo, onipresente no "Poema sujo" (1975) ou em tantos outros versos daqueles anos, como em "O poço dos Medeiros" (Na vertigem do dia, 1975-1980) no qual afirmava: "Não quero a poesia, o capricho/do poema: quero/reaver a manhã que virou lixo", e considerava o poema uma mentira, porque simulacro da vida.

Laura Vinci, em sua defesa, remonta à tradição da pintura da natureza morta, mas não chega a referir-se à influência que, consciente ou inconscientemente, recebeu da antiarte dos anos 70. Pois a provocação que seu trabalho propõe para a crítica parece-nos advir diretamente dos questionamentos daquele período, embora tenha havido uma transformação, a que queremos aludir no final. Por exemplo, o poeta e letrista Waly Salomão apelidou um conjunto de textos e colagens compostos ao longo da década de 70 de "Babilaques" e conferiu-lhes o epíteto de "arte still alive".

Estes "babilaques" são páginas de caderno nas quais ele foi escrevendo, desenhando, colando fotos, como um misto de diário, carta, e reflexão poéticovisual. O nome inventado lembra badulaque, penduricalho, babilônia. Não se trata de obra para ser editada em livro e sim um tipo de criação compulsiva - como um aspirador de todas as impressões, sugadas e espalhadas. Apenas alguns deles foram publicados em revistas alternativas nos anos 70 e 80 . O interlocutor provável é certamente ele mesmo, em primeiro lugar, e logo em seguida os amigos artistas e poetas - uma entourage de pessoas afins que pudessem partilhar seus interesses de forma íntima.

O poeta Antonio Cícero, comentando um texto inédito de apresentação dos "babilaques" escrito por Waly, ressalta que este não os considerava simplesmente poemas visuais mas "performance poético-visual", uma vez que neles se combinam escrita e formas plásticas de desenho e montagem:

Trata-se, portanto, da arte still alive, da arte ainda viva, da arte que permanece viva. Assim quer ser o Babilaque: "a composição enquanto presença dalguma coisa". A presença surge "dentro da composição através dela pela primeira única vez", quando, numa performance poética, o artista põe ou surpreende, por exemplo, tal pedaço de fruta dentro de tal lata vazia. E "a fotografia”, como diz Waly na nota inédita já citada, "com seus elementos composicionais próprios: luz, cor, ângulo, corte - transforma e ficciona a performance poética”. (Cícero, 2007: 28) 
A expressão "still alive" parece denotar, de um lado, um desejo de resistência, como se a arte não abdicasse do seu direito de existir e, de outro, o reconhecimento de sua efemeridade e pouca centralidade no mundo da mercadoria no qual as sete mil maçãs vêm do Ceasa (o maior centro de abastecimento de alimentos da cidade). A referência ao pai da arte moderna, Cézanne, tanto por Vinci quanto por Gullar, não é nada gratuita, uma vez que foi com seus experimentos pictóricos que o realismo plástico começou a dissolver-se, tendo então alcançado seu apogeu. Igualmente, faz ressoar o diálogo com desafios enfrentados nos anos 70, em que a literatura e as artes visuais precisavam defender-se do inimigo que de dentro e de fora as acossava, como reconhece o mesmo Waly Salomão no livro Me segura qu'eu vou dar um troço (1972). Nessa obra, a pressa ansiosa de tudo dizer, concomitante ao temor de ser logo calado, infiltra-se na própria estrutura da escrita, em seu estilo fragmentado e histérico e vai comparecer em grande parte da poesia mais experimental da época (por motivos políticos, existenciais, culturais que não caberia desenvolver aqui).

O crítico Roberto Zular, ao comentar o mencionado livro, identifica o gesto performativo que quer inserir-se no texto como traço paradoxal dessa escrita quase presencial. Tal tentativa-limite "aponta uma busca desesperada de aproximação entre corpo e palavra." (Zular, 2005: 51). Comparando sua escrita em processo com as experiências de criação do grupo Fluxus, de Hélio Oiticica e de Yoko Ono, ressalta o aspecto proposicional de suas obras, em que o leitor (ou espectador) "é chamado a participar do processo de produção". Assim, o livro ganha um ar de inacabado, de rascunho reiterado, uma vez que estamos diante de um "questionamento constante das suas condições de enunciação.” (Idem, 53).

Reencontramos essa urgência aflita e impotente, por exemplo, nos escritos elípticos de Ana Cristina Cesar (poeta cuja produção principal se concentra nos anos 70 ou começo dos 80) nos quais o "excesso de presença" parece desejar alcançar o aqui e agora impossível, conforme se verifica nestes trechos de poemas a seguir:

3 Expressão de Gilles Deleuze utilizada por Annita Costa Malufe, que deste modo analisa a histeria na literatura contemporânea, o que se traduz em textos com "movimento descontínuo, caótico, de frases entrecortadas, fragmentárias, de ritmo acelerado, ofegante" no capítulo "Afectos femininos da escrita" de seu livro (2006). 
Não, a poesia não pode esperar.

O brigue toca as terras geladas do extremo sul.

Escapo no automóvel aos guinchos.

Hoje - você sabe disso? sabe de hoje? Sabe que quando

digo hoje, falo precisamente deste extremo ríspido,

deste ponto que parece último possível?

(Inéditos e dispersos, 1985, póstumo)

Ou:

Não querida, não é preciso correr assim do que vivemos. $\mathrm{O}$ espaço arde. $\mathrm{O}$ perigo de viver.

(Idem)

Ou ainda:

No verso: atenção, estás falando para mim, sou eu que estou aqui, deste lado, como um marinheiro na ponta escura do cais. É para você que escrevo, hipócrita.

(em "Fogo do final", A teus pés, 1982)

A urgência em relação ao tempo transmite a impressão de que o poema é o testemunho do último minuto e demanda a incorporação impossível da linguagem ao corpo, locus da experiência mais interna, exprimindo-se em metonímias abruptas, como se não houvesse fôlego para dizer mais do que o essencial daquele evento fugaz, agarrando o leitor e colocando-o no centro do poema, que quer acordá-lo, como um "despertador", que "bate nas pálpebras como/se bate numa porta a socos" (João Cabral).

No entanto, essa gana pelo presente (e pela presença) é concomitante à consciência de sua impossibilidade, como se observa no poema de Ana Cristina "Le ballet de l'Opera a Rio" (Antigos e soltos, 2008, póstumo). Nele, o eu-lírico propõe ao leitor entregar-se à "ilusão de transe" que parece acometer os bailarinos quando dançam - algo que só a platéia, na verdade, experimenta: "a violência/com que (imaginamos)/ os bailarinos fetichizados se erguem/em êxtase/em transfiguração". A diagramação imita os movimentos da dança, sugerindo o ímpeto de alcançar, pela palavra, a fusão perdida com 
algum rito original, que a arte propiciaria antes da cisão moderna entre indivíduo e mundo. Deste modo, o poema evidencia a fratura entre "mundo em comum" e transfiguração estética. Assim, o movimento do querer anuncia o que se perdeu. A inocência já foi rompida pela separação do puro arrebatamento e da construção: entre a "machine à emouvoir" e o bastidor há um hiato a que o verso "desejo escrever com violência para consolar-te" alude, uma vez que a utopia de comunhão plena consigo mesma e com as forças inaugurais panteístas foi fraturada por força da consciência dividida de si.

Ora, desde a "Teoria do não-objeto", que Ferreira Gullar publicou pela primeira vez em 1959, acompanhada a seguir pelo texto "Manifesto neoconcreto", o poeta e crítico propunha a destruição dos objetos artísticos convencionais, sugerindo que a pintura rompa "a moldura para que a obra se verta no mundo" (2007: 94), de forma que o artista não mais se contente em "erguer um espaço metafórico num cantinho bem protegido do mundo, e sim" que cumpra a determinação "de realizar a obra no espaço real mesmo" (Idem, 92).

Para Gullar, a arte deveria intervir no real, criando situações que alterassem a percepção, principalmente mudando o espaço em que vivemos. Enfim, ao contrário de hoje, naquele momento ele propugnava a radicalização da experiência artística, instando-a a misturar-se ao mundo, exigindo a intervenção do leitor-participante e afirmando que se a realidade é inconclusa, também a obra deve fluir, modificar-se... Reclamava sobretudo uma poesia engajada na carne das coisas, nos barulhos, na experimentação da luta corporal, em que se rejeitasse a técnica poética exterior, como se a linguagem não existisse antes do poema. No "Manifesto neoconcreto" (1959) e em outros textos da época, o espectador é chamado à interação com a obra, que passa a fazer parte da realidade, extravasando a moldura para entrar no espaço comum. ${ }^{4}$

Gullar imagina um tipo de arte que se confunda com os objetos do mundo:

Quando rompo a moldura, destruo esse espaço estanque, restabelecendo a continuidade entre o espaço geral do mundo e meu fragmento de superfície. O espaço

4 "O não-objeto reclama o espectador (trata-se ainda de espectador?), não como testemunha passiva de sua existência, mas como a condição mesma de seu fazer-se. Sem ele, a obra existe apenas em potência, à espera do gesto humano que a atualize." e "A arte não é uma atividade de segundo grau mas um ato primeiro que muda o mundo." (Ferreira Gullar, "Teoria do não-objeto", 1959, e "O tempo e a obra", 1961, Supl. Dom. do Jornal do Brasil, republicado em 2007, p.100 e p. 110 respectivamente). 
pictórico se evapora, a superfície do que era "quadro" cai ao nível das coisas comuns e tanto faz agora esta superfície como a daquela porta ou daquela parede. Na verdade, liberto o espaço preso no quadro, liberto minha visão e, como se abrisse a garrafa que continha o Gênio da fábula, vejo-o encher o quarto, deslizar pelas superfícies mais contraditórias, fugir pela janela para além dos edifícios e das montanhas e ocupar o mundo. É a redescoberta do espaço. ("Lygia Clark, uma experiência radical", 2007: 83 [1958])

Mário Pedrosa já considerava, em seu texto "Arte ambiental, arte pós-moderna”, de 1965 (apud Oiticica, 1986) que entráramos em novo ciclo cultural: era o fim do ciclo da arte moderna inaugurada pelo cubismo das "Demoiselle d' Avignon", de Picasso. Não mais uma arte intelectual e pura, mas uma antiarte, em que estruturas perceptivas e situacionais se sobreporiam aos valores puramente plásticos.

A geração rotulada como marginal, que certamente dependeu bastante da influência do pós-tropicalismo de Waly Salomão e Torquato Neto, recusava o suporte do "livro bibliotecável", preferindo as formas precárias semi-artesanais e personalizadas de expressão, ao mesmo tempo que as artes plásticas tendiam para as chamadas "manifestações ambientais" - eventos que se realizavam desde o final da década de 60, coletivamente, e se esgotavam no seu acontecimento, sem transcendência material. Assim, a concepção de arte como evento único no presente, circunscrito a seus participantes como acontecimento pontual, contrariava violentamente a idéia mais tradicional de uma arte que produz objetos perenes. ${ }^{5}$

Recentemente, o crítico Alberto Tassinari (2001) desenvolveu esta idéia lançando como hipótese a divisão das artes plásticas modernas em duas fases: a primeira, de formação (a partir de 1870) e, a segunda, de desdobramento (a

5 Um grupo de estudiosos argentinos vem estudando a arte e a literatura brasileira contemporâneas e tem pesquisado o ponto de virada que esta época significou. Nos últimos anos, publicaram diversos textos importantes que refletem sobre este período. Destaco os nomes de Florência Garramuño, Gonzalo Aguilar e Luciana di Leone. A inflexão da arte do visual para o tátil ou sensorial é uma de suas preocupações teóricas assim como a importância do acontecimento como experiência única. Observa Florência Garramuño que uma "grande quantidade de textos e práticas artísticas que começam a surgir a partir da década de 70" tendem a relativizar "uma noção de obra como constructo autônomo e impermeável a um exterior ou 'fora' da obra." (2007, p. 11). 
partir de 1955). A arte contemporânea, ou pós-moderna, seria uma continuação da moderna sem os resquícios pré-modernos que provocavam conflitos: estes foram superados ou atenuados, de modo que não houve ruptura ou mudança radical entre a primeira e a segunda fases.

Para o crítico Steinberg, citado pelo autor, a pintura tornou-se mais um lugar do "fazer" em oposição ao tipo de obra mais tradicional, que era relacionado ao "ver". No período de formação da arte moderna, ela ainda é em parte naturalista e em parte a destruição do naturalismo. Mas esse processo termina na época contemporânea, a partir de Jasper Johns, Pollock e outros: o resíduo naturalista esgota-se quando a tela aparece no produto final, por exemplo. Deixar à mostra os processos operacionais e romper os contornos já eram procedimentos das primeiras vanguardas, que se tornaram onipresentes hoje. $\mathrm{O}$ fato de que a arte contemporânea tende a ser interativa, desmontável e mesmo descartável ou, ainda, participa do espaço comum do mundo, pode levar o espectador a não mais distinguir entre um fenômeno estético e outro não estético. A autonomia da arte corre risco quando o espaço de uma obra não se separa com nitidez do espaço do "mundo em comum". Já as obras de arte anteriores, mesmo as ruins, não colocavam esse problema, pois tinham seu espaço próprio emoldurado e bem contornado. Não levantavam a pergunta "isso é arte?". Hoje, mesmo obras interessantes "podem passar por simples coisas jogadas no espaço em comum” (Tassinari, 2001: 56).

O modelo proposto pelo crítico é a escultura "Arco inclinado" (1981) de Richard Serra, em que uma parede curva e ondulada de ferro é colocada numa praça, dividindo o espaço sem que o passante saiba de antemão que se trata de uma escultura.

Observamos que o mesmo questionamento pode ser encontrado na poesia brasileira, especialmente a rotulada como marginal ou pós-tropicalista, a partir dessa época. O coloquialismo e a mescla de gêneros, tendo começado no modernismo como ruptura, radicalizou-se muito mais a partir dos anos 70. Deparamo-nos com um tipo de texto literário indiscriminado entre carta, diário, poema, reflexão, ou o poema sem nenhum "pedestal" ou "moldura", compartilhando totalmente da linguagem comum, como se não fosse um artefato artístico.

Tassinari utiliza a expressão "espaço em obra" para definir esse novo modo da arte apresentar-se, que se assemelha mais a um fazer, algo que exibe sinais evidentes de sua construção, ao mesmo tempo em que há um "rompimento do 
contorno" (moldura e pedestal, nas artes plásticas; verso e metro, na poesia). O crítico exemplifica com uma pintura de Rauschenberg intitulada "Cama", a qual transpõe para o quadro pedaços de matéria bruta, que fazem com que o quadro seja quase um objeto real: uma "pintura-coisa", na expressão de Argan.

De certa maneira, vários textos de Ana Cristina Cesar, Waly Salomão, Torquato Neto, Cacaso e Francisco Alvim oferecem esse jogo entre exposição do processo e momentos de acabamento, como se houvesse por vezes um desnudamento do fazer literário, uma exposição crua de seus andaimes: são poemas-conversa - entre arte e vida cotidiana. Em Ana Cristina, o trabalho de inserir trechos de conversas em meio a jogos de palavra, imagens, reflexões, cria esta impressão de indecidível cruzamento entre carta, diário, conversa transcrita ou texto poético. Francisco Alvim dá a impressão de transmitir a "voz dos outros", que recorta e expõe. Cacaso se auto-denomina "o poeta que escuta" e muitas vezes seus versos ecoam a proposta de um "poemão" coletivo, escrito por toda sua geração.

Enquanto na arte "naturalista" (termo que o crítico estende a toda representação realista a partir do Renascimento), ocultam-se as estratégias do fazer porque se necessita da ilusão; na arte contemporânea, pelo contrário, estas são expostas.

O espaço do mundo em comum, quando solicitado pela obra, passa a fazer parte dela, ao mesmo tempo em que continua a ser cotidiano, sugerindo certa duplicidade. É o que reconhecemos nos poemas de Francisco Alvim, em que frases por ele capturadas na rua, na família e no trabalho se transformam em versos de poema, mas mantêm a ambigüidade de continuarem a ser palavras ditas comumente. Ao entremeá-las com poemas líricos, em que imagens da natureza desempenham função metafórica, ele obriga o leitor ao duplo movimento de entrar e sair da obra, provocando a estranheza do ready-made, que explora essa zona de fronteira, ao lado do objeto estético no mesmo espaço, com a intenção de perturbar o estatuto da obra. ${ }^{6}$

A poesia dos anos 70 busca um caminho de mão-dupla, produzindo poemas que contêm muito da fala comum combinada a imagens e reflexões mais formalizadas. Tal composição resulta na indeterminação, na sensação de inacabamento e espontaneísmo, e finalmente, na possível dúvida sobre se

6 Remeto a texto em que comento a interligação entre seus diferentes tons poéticos, no qual desenvolvo melhor o aqui mencionado, com exemplos e comentários: "As faces da musa em Francisco Alvim", Poéticas do olhar e outras leituras de poesia (2006), org. Célia Pedrosa e Maria Lúcia de Barros Camargo. Rio de Janeiro: 7 Letras. 
aquilo é uma fala retirada imediatamente da vida, sem transfiguração estética alguma: "A obra se expõe emergindo do cotidiano sem nunca dele desgarrarse." ('Tassinari, op. cit.: 93). Diferentemente da obra de arte autônoma a partir do Renascimento, que convida o espectador a nela colocar-se inteiramente, emergindo do mundo comum para vê-la e compreendê-la, aqui ele "não abandona inteiramente o mundo em comum mesmo quando solicitado para o mundo da obra" (Idem, 95). Há um vai-e-vem constante, em que a visão e o pensamento não são transportados totalmente.

Por isso, o espectador não é totalmente abduzido para dentro da obra, uma vez que seu fazer e o espaço em comum com o mundo ficam expostos. $\mathrm{O}$ fato da obra não ser um conjunto unívoco também provoca essa reação de pouca entrega. A incompletude torna-se característica da obra, seja porque se espera que o leitor preencha as elipses pela sua interpretação, seja porque as fronteiras entre as partes entram em atrito, sem resolver-se em configuração coesa. Muitas vezes é difícil decodificar as relações pouco orgânicas, pois as associações não são necessariamente contíguas.

$\mathrm{Na}$ dramaturgia a partir do final dos anos 60, tal transformação é clara: enquanto no teatro tradicional somos arrebatados para dentro do ambiente da peça, vivendo o drama das personagens, no teatro pós-brechtiano, tal como praticado pelo Oficina a partir do "Rei da vela" (1967), por exemplo, a montagem é exposta: o ator entra e sai de seu papel e o lugar do espectador é posto em xeque. ${ }^{7}$ Assim, não vivemos uma experiência de transporte completa: somos devolvidos à vida comum de forma intermitente e chamados a interagir com a obra, que não se perfaz sem este movimento.

Além do debate recorrente "isto é arte?" ou "se isto é arte, o que é arte?" (extensivo a "isto é mesmo poesia?") sucede-se a controvérsia correlata "será que a arte, tal como a reconhecemos, acabou? (e o que se faz hoje é só uma reprodução ou variação de algo esgotado?)" - são problemas que se avolumam nos anos 70, ao lado de indagações já mais antigas sobre se a arte abstrata não seria elitista e meramente ornamental, sem função crítica, algo asséptica em seu formalismo, enquanto se demandava um tipo de arte mais "útil", que represen-

7 Cito um trecho do convite-manifesto da peça "Gracias Señor" (1972), de José Celso: “O único papel do teatro/é levar as pessoas pra fora dos teatros./Destruir teatro onde houver teatro/Construir teatro onde não houver teatro./Chegar na frente da televisão/Quebrar o vídeo e dizer: qual é?/- Eu tô vivo!/ Eu estou vivo, bandeira é estar vivo!" (apud Sussekind, 2007: 51) 
tasse criticamente um aspecto do real a ser denunciado - uma arte de cunho imediatamente político, que não se mantivesse simplesmente como expressão de um sujeito encapsulado e fosse sinal dos tempos. Então, se de um lado, a poesia concreta, ao produzir uma arte serial, industrial, urbana, considerava-se mais engajada com a realidade contemporânea, de outro, os poetas ligados ao $\mathrm{CPC}^{8}$ se auto-enxergavam como devotados à causa conscientizadora, confiando que falavam a linguagem do povo. E, por fim, por que não? também os marginais supunham algo semelhante a respeito do próprio trabalho: acreditavam estar se aproximando do cotidiano.... enfim, todos propunham lutar contra velharias sublimadoras, ilusórias e ir ao encontro do mundo da vida, fazendo algo que, se era arte, incluía também aspectos de outros campos - o político, o relacional, o psíquico. A idéia da necessidade de destruir a arte como instituição, ou transformála radicalmente, está presente em muitas vertentes. Enquanto os artistas plásticos desejavam abandonar o museu e as galerias para criar uma arte performática que interagisse com o público, agora "participador", o poeta também compunha um livro coletivo, feito para ser parte do cotidiano e que conversasse com os leitores.

$\mathrm{O}$ artista plástico Helio Oiticica reforça estes argumentos afirmando que a arte deve ser um acontecimento participativo e embasando-se na teoria do não-objeto de Gullar, propõe outros nomes, como "transobjeto" ou mesmo "probjeto" (que inclui a idéia de projeto, inventada pelo tropicalista baiano Rogério Duarte para a exposição coletiva Apocalipopótese, de 1968). ${ }^{9}$ A criação contínua como um "exercício experimental da liberdade" anima-o a conjugar o próprio fazer da obra com a vivência do indivíduo a quem se apresentam essas novas formas - "proposições abertas, não condicionadas":

Parangolé é a antiarte por excelência; inclusive pretendo estender o sentido de "apropriação" às coisas do mundo com que deparo nas ruas, terrenos baldios, campos, o mundo ambiente, enfim - coisas que não seriam transportáveis, mas para as quais eu chamaria o público à participação - seria isto um golpe fatal ao conceito de museu, galeria de arte,

8 Os Centros Populares de Cultura, organizados pela União Nacional dos Estudantes (UNE) congregavam artistas de várias áreas durante os anos 60 , com a intenção de criar e divulgar uma arte dita nacional-popular, de intenção claramente política, cujo objetivo era o de conscientizar o público das injustiças políticas e sociais (ver o "Anteprojeto do manifesto do CPC", de Carlos Estevam Martins, republicado em Arte em revista n. 1. São Paulo: CEAC, 1979.

9 Para uma visão circunstanciada das idéias de Gullar e Oiticica sobre arte, em suas semelhanças e diferenças, leia-se o estudo de Carlos Zílio, "Da Antropofagia à Tropicália” (1982). 
etc., e ao próprio conceito de "exposição" - ou nós o modificamos ou continuamos na mesma. Museu é o mundo; é a experiência cotidiana [...] (Oiticica, 1986, 78-79).

Desde os penetráveis e parangolés de meados dos anos 60 (e ao longo dos anos 70), Oiticica recusava-se à produção de uma obra fixada no objeto artístico. Influenciado pela arquitetura precária das favelas, procurava soluções coletivas para sua produção, "à espera de um sol interno" utópico que iluminasse a vivência de cada "participador", negando-se a expor em galerias ou museus que desvirtuassem a relação entre artista, obra e público. Também os poetas em seus textos da época anseiam por uma eletrização do momento atual, colocando em causa o poema como forma perene.

Nos anos 70, Oiticica propugnava uma arte "suprassensorial" em que os estímulos externos fossem mínimos e em que a percepção do evento estivesse centrada no sujeito. Nota Sussekind (2007: 50) que os artistas sublinhavam, naquele momento, a realização de atos inesperados e espontâneos que intensificassem a sensação do tempo presente.

Lygia Clark, por sua vez, no texto "Da supressão do objeto", publicado na revista Navilouca (1974), que congregou artistas plásticos e poetas, afirmava que se fazia necessário exprimir-se diretamente. Seria através da exposição do próprio corpo? Alguns artistas concluíram que sim, mas a ela parecia regressivo usar-se, transformando a si mesmo em objeto (agredir-se, estar presente, cortar a tela, fazendo do corpo o suporte). A crise geral de expressão, sugeria, poderia ser superada por uma perda incorporativa da identidade. Propunha, então, um caminhar (metafórico?) em que o eu se dissolveria no coletivo, pois os atos particulares se integrariam na existência de todos, e a autoria individual não mais importaria: "Sinto a multidão que cria em cima do meu corpo, minha boca tem gosto de terra". Erotismo panteísta que pressupõe a atitude de estar colada ao fluxo da experiência: "receber as percepções em bruto sem passar por qualquer processo intermediário" (1974: 82-85).

Outro artista (por sinal português, mas na época morando no Brasil), Artur Barrio em 1969, lança um manifesto, do qual selecionamos algumas partes:

contra as categorias da arte

contra os salões

contra as premiações 
contra os júris

contra a crítica de arte

$\cdots$

faço uso de materiais perecíveis, baratos, em meu trabalho... materiais precários ${ }^{10}$

Como no caso dos poetas marginais, ele se rebelava contra a forma mercadológica da divulgação e circulação de seu trabalho artístico, além de se insurgir contra qualquer categorização autonomizante, preferindo criar com um material que se opusesse à eternização - de modo similar ao aspecto informal dos livrinhos da geração mimeógrafo. Ainda ressaltava o "contato com a realidade", especialmente com "tudo que é renegado". Acrescenta, mais tarde, que, na sua produção, "as coisas não são indicadas (representadas) mas sim vividas" - muito similar à assunção de Cacaso, tomada como lema pelos outros poetas de sua geração ("a vida não está aí para ser escrita, mas a poesia sim está aí para ser vivida") ou de Torquato Neto ("Um poeta não se faz com versos").

De fato, suas obras da época são realizadas com lixo. As mais conhecidas se tornaram as "Trouxas sangrentas" - pedaços de pano que embrulham vísceras e outros materiais orgânicos, amarrados com barbante, como se fossem troços, corpos abandonados... que ele jogava em rios ou terrenos baldios, com o objetivo de causar choque nos transeuntes. Chamava-os "objetos deflagradores", filmando e fotografando a reação dos passantes (já predispostos ao medo, pela presença do Esquadrão da Morte nas cidades satélites cariocas). ${ }^{11}$

10 Reproduzido no livro dedicado ao artista da coleção "Arte contemporânea". Rio de Janeiro: MEC/ Funarte, 1978.

11 Nas artes plásticas brasileiras, lembramos ainda a aparente "imediaticidade" de Antonio Manoel que, em noite de estréia de exposição coletiva, desce nu as escadas do MAM apreentando seu trabalho "Corpobra" (1970), e argumenta que o corpo é a obra - e é preso imediatamente... Cildo Meireles carimba frases em notas de dinheiro que circulam, como "Quem matou Vladimir Herzog?" Letícia Parente exibe um vídeo em que aparece um pé sendo costurado com a expressão "Marca registrada" (1975). Regina Silveira se fotografa comendo biscoitos em forma de letras que compõem a palavra ARTE (1976). Waltércio Caldas coloca um círculo de arame no chão do museu, no limite do qual prende dois sapatos e o intitula "A emoção estética" (1977), a ironizar a distância da contemplação. Hudinilson Jr. tira xérox de partes do seu corpo e as fotografa para uma exposição (1979), tendo criado no ano anterior um coletivo batizado de 3nós3 que, dentre outras intervenções urbanas, lacrou com fita crepe as portas das principais galerias da cidade. Ivald Granato sai em procissão carnavalesca na Rua Augusta, com a presença de Hélio Oiticica fantasiado e outros, numa performance que chamou de "Delírio ambulatório" (1978). 
Algo análogo acontecia no reino da poesia chamada pós-tropicalista ou marginal, dependendo do grupo ao qual o poeta pertencia naquele momento. Ambas desconstruíam o construtivismo concretista predominante desde meados dos anos 50 e se diziam anti-formalistas e aderentes à prática vital, que se recusavam a mediar pelo distanciamento necessário à simbolização. Parece-nos que a produção de Ana Cristina Cesar, Francisco Alvim, Waly Salomão e Torquato Neto - e, porque não, Ferreira Gullar - seriam paradigmáticos dessa crise extrema que os anos 70 representam, em rebelião contra a sociedade de mercado e contra a repressão política. Também ele, desde os experimentos concretas, intentava, como nas artes plásticas, superar uma linguagem que já apalpava muros de aprisionamento: "O que importa não é fazer um poema - nem mesmo fazer um não-objeto - mas revelar o quanto de mundo se deposita na palavra." (2007: 99 [1959])

Seu "Poema sujo", um dos mais poderosos textos da década de 70, sintetiza os embates entre construção e imersão na existência, recriando a poesia de novo, aproximando-se da lama, dos cheiros, do nascimento e podridão das coisas. Embora Gullar estivesse no exílio na época e fosse de uma geração bem mais velha que os poetas marginais que surgiam naquele momento, há neste poema confluência de espírito muito profunda com o movimento de acercar-se visceralmente do corpo dos seres, recomeçando a poesia, como intentavam fazer os jovens de incipiente produção nos anos $70 .^{12}$

Não se pode negar certa afinidade entre os questionamentos enfrentados pelas artes plásticas e pelos poetas marginais, ao partilharem a postura antitradicional, a realização da obra em grupo, de modo artesanal e perecível, a ida às ruas e a desconfiança em relação à arte autônoma e transcendente. Os livros de Chacal e Charles são um exemplo bem característico: pequenos e coloridos, muito ilustrados, feitos com a ajuda de amigos, referem-se a experiências repartidas pelo grupo geracional, com ecos em surdina da situação do país.

Assim, no texto manifesto "Mamãe Belas-Artes", publicado no tablóide alternativo e coletivo Beijo n. 2 (1977), e assinado pelo crítico e poeta Ronaldo Brito e

12 É justamente Ferreira Gullar, um dos mentores intelectual dessas mudanças, grande amigo de Mário Pedrosa, que considerava, naquele momento, que "os três radicais do movimento, passadas suas experiências, haviam deixado praticamente de ser artistas: Hélio Oiticica escolhendo a marginalidade, Lygia Clark a terapia e ele a sua África: a política cultural de esquerda”, apud Wilson Coutinho (1998), "Gullar, crítico de artes plásticas", p. 112. 
pelo artista plástico José Rezende, ambos recusam, da forma peremptória típica da época, o que chamam de monumentalização da arte e seu status de objeto como valor de troca, afirmando que "O meio de arte brasileiro resiste à produção contemporânea e à sua mais grave exigência: a liquidação definitiva do sistema das Belas-Artes." Enfatizando a crise que começou em Cézanne e se radicalizou nas vanguardas, atribuem-lhe como causa o "questionamento do lugar social da arte." Haveria, portanto, algo de inadequado e mesmo "ridículo" na relação entre os objetos produzidos e o espaço dos museus e galerias onde são expostos. $\mathrm{O}$ termo "vazio cultural", segundo os dois, refletiria essa dificuldade de perceber o que estava sendo feito de fato, preferindo-se pensar que nada estava acontecendo, uma vez que a produção contemporânea não correspondia ao parâmetro esperado. $\mathrm{Na}$ mesma época, também a apresentação da revista "Almanaque Biotônico Vitalidade" (1976-1977), produzida pelo grupo de artistas conhecido como "Nuvem cigana", evoca uma atitude de rebeldia, que se repete na apresentação que dois poetas, Bernardo Vilhena e Eudoro Augusto, redigem para uma antologia da poesia da época, "Consciência marginal" (editada numa revista do Rio produzida por poetas e artistas plásticos, a Malasartes, 1975, n. 1), na qual afirmam que "a poesia não cabe em estantes programadas, (...) não foi incorporada ao comércio de livros e à cotação periódica dos artefatos consumíveis”.

Voltando ao presente, e retomando a polêmica à volta da exposição de Laura Vinci, o pesquisador e curador de arte contemporânea Moacir dos Anjos, respondendo às restrições de Gullar e de outro crítico, Luciano Trigo ("É de fama e dinheiro que se trata a arte?", Folha de S. Paulo, 19/11/2007), procura justificar a instalação "Ainda viva" comentando que "o roçar entre maçãs vermelhas perecíveis e a solidez branca e esculpida do mármore" constitui uma "locução simbólica do momento e do espaço em que vivemos nós todos." ("É do mundo que a arte trata”, Folha de São Paulo, 20/11/2007). ${ }^{13}$ O melhor texto de defesa talvez tenha sido o de Paulo Sérgio Duarte, "Muito além da aflição" (no catálogo da exposição), em que o crítico observa o contraste entre o tempo acelerado e burocrático da vida moderna e o tempo no

13 O debate continuou ainda com outras réplicas e novos agregados pró e contra. Um articulista do mesmo jornal, Marcos Augusto Gonçalves, retomou o célebre título de artigo de Monteiro Lobato, "Paranóia ou mistificação" (em que nosso melhor escritor de histórias infantis desancava a arte moderna, encarnada pela suposta degeneração doentia dos quadros de Anita Malfatti) para defender a arte contemporânea da pecha de repetição degradada das vanguardas (22/11/2007). 
entanto lento das maçãs, em seu ritmo natural de apodrecimento, durante o qual longamente ainda exalam cor vibrante e perfume. Ao invés da efemeridade, ele destacou a duração e a beleza - aspectos pouco ressaltados na arte dos anos 70 - de certa forma mostrando uma diferença sutil, como se hoje pudéssemos retomar aquelas questões com mais complexidade.

A arte certamente voltou aos museus e às galerias, assim como a poesia aos livros produzidos e distribuídos pelas editoras. Mas a ferida aberta nos anos 70 não pode ser ignorada pois sua cicatrização apresenta uma marca indelével sob a forma aparentemente apaziguada do objeto artístico, a partir de então ainda mais contraditório: ${ }^{14}$ aponta tanto para as maçãs quanto para o mármore, paradigmáticos seja da nossa consciência da temporalidade precária seja do momento da figuração formal, como uma resistência, breve que seja, do desejo de beleza.

O mesmo se nota na poesia de Gullar, antes suja e delirante, girando num disparo para vários lados simultâneos, e agora tão depurada, ainda que tratando dos mesmos traumas. É verdade que desde o começo de sua obra, peras e bananas o acompanham (e por que não maçãs?) como metáforas do tempo que passa, consumindo-se inutilmente, e indicando a brevidade do homem e do seu canto. Tal tema, com ecos existenciais e estéticos, acompanhou-o ao longo de toda sua obra, até seu livro mais recente em que também a oposição entre o orgânico e o mineral o assombra. Em "Visita" (Muitas vozes, 1999), quando busca conversar com o filho morto no cemitério, compreende que nem a flor nem a palavra escrita resistem frente ao mármore do túmulo, pois o poema é impotente para vencer a morte. Como toda a crítica sempre enfatizou, a principal veia temática de sua obra é o assombro com a passagem inexorável do tempo, em contraste com a fragilidade da vida, que acontece "na vertigem do dia", “dentro do presente veloz". ${ }^{15}$ Sua arte parece reiterar esses

14 Artur Barrio continua a coletar detritos e resíduos de todo tipo, mas os dispõe em configurações abstratas, dentro de quadros emoldurados que expõe em galerias, numa atitude paródica, talvez agressiva ("Desenhos", 2008). Por outro lado, Waltercio Caldas produz séries elegantes e de sutil ironia, como uma sala em que se distribuem maçãs de cera iguais às reais sobre mesas simétricas, que parecem refletir-se umas às outras através de estruturas de vidro e aço, como finas alusões a molduras ("Maçãs falsas", 2008). 15 Nesse sentido, concordam as análises de João Lafetá, Alcides Villaça, Alfredo Bosi e Leonardo Martinelli, enfatizando essa temática como central à obra de Gullar. Em vários poemas que giram à volta da imagem da fruta que apodrece, o dilema entre a fugacidade da vida e a composição artística, por meio de palavras poéticas que, pela sonoridade e pela imagem, perenizam a experiência, é aguçado ao máximo. Nesse sentido, evidencia-se a diferença com as artes plásticas, que, ao tematizar a efemeridade e a 
dilemas, em Barulhos e Muitas vozes (seus livros mais recentes) observando o quanto a palavra poética é feita de ar, uma "não-coisa" escrita por "muitas vozes", que não apreende a densidade dos seres nem impede a sua corrosão.

A depuração se deu também em outros poetas de longo curso, como Armando Freitas Filho, ${ }^{16}$ que, fiel à exposição permanente do processo de feitura, passou da urgência aflita para o refinamento desta. Obcecado pela passagem do tempo, intentava pular para dentro do poema enquanto o escrevia. Agora se observa em sua obra momentos de distensão lírica, ao lado da perseguição do presente inalcançável.

Embora concordemos com Gullar que grande parte das obras expostas nas Bienais seja um prolongamento repetitivo dos mesmos desafios já exauridos pelas vanguardas e seus desdobramentos, ressalvamos que, nos melhores casos, a antiarte tornou-se constitutiva da arte, como uma fissura que penetra as formas simbólicas, inconciliável com elas, mas que ainda assim precisa ser incorporada em tensão não resolvida. $\mathrm{O}$ artista nem pode aderir a ela (permanecendo na imediaticidade agora ingênua) nem ignorá-la (propondo-se à realização de uma forma artística orgânica) - ambas atitudes anacrônicas. De fato, muitas vezes a apresentação de palavras e objetos que não sofreram a interferência da reflexão e da transfiguração promovidas pelo trabalho e pela consciência do artista parece-nos mal resolvida e pouco instigante. A precariedade formal não é, evidentemente, uma característica a ser considerada, em si mesma, qualidade.

$\mathrm{O}$ artista precisa transformar o risco em ritmo e transitar entre a presença e a sua metaforização em linguagem (adaptando aqui o vocabulário de Meschonnic), para abrir uma via que atualize a afirmação de Laura Vinci quando da defesa que fez de sua exposição: "isso é uma pergunta sobre o destino da arte"... ou, na mesma linha, esta reflexão recente de Waltercio Caldas: "É da natureza dos objetos de arte preservar, mesmo depois de concluídos, o seu destino de hipótese."

\footnotetext{
urgência da vida contemporânea, podem ser mais literais, uma vez que incorporam matérias "reais", em estado bruto, criando um tipo de ambigüidade entre o imediato e o mediado que a palavra, por ser de natureza simbolizante e necessariamente representação, pode mimetizar sem nunca ser de fato "coisa". 16 A respeito do diálogo entre poesia e artes plásticas, assim como entre o construtivismo e o visceral, na obra de Armando Freitas Filho, leia-se o ensaio "O olhar eloqüente" de Célia Pedrosa em que a pesquisadora desenvolve reflexão ampla sobre os debates estéticos dos anos 60, à volta dos escritos de Mário Pedrosa e de Ferreira Gullar (2006).
} 


\section{Referência Bibliográfica}

CALDAS, Waltercio (2006). Notas, () etc, Livro do Artista. São Paulo, Gabinete de Arte Raquel Arnaud.

CÍCERO, Antonio (2007), “Os Babilaques de Waly Salomão”, Revista Z Cultural, Ano IV, n. 1, dez. Republicado em Waly Salomão. Babilaques: alguns cristais clivados. Rio de Janeiro, Contra Capa Livraria/Kabuki Produções Culturais.

CESAR, Ana Cristina (2008), Antigos e soltos, org. Viviana Bosi, São Paulo, Instituto Moreira Salles. . (1982), A teus pés. São Paulo, Brasiliense.

. (1985), Inéditos e dispersos, org. Armando Freitas Filho, São Paulo, Brasiliense.

COUTINHO, Wilson (1998), "Gullar, crítico de artes plásticas" in Ferreira Gullar. Cadernos de Literatura Brasileira, São Paulo, Instituto Moreira Salles.

GARRAMUÑO, Florência (2007), "La experiência y sus riesgos” in Garramuño, Florencia/Aguilar, Gonzalo/di Leone, Luciana (orgs.) Experiencia, cuerpo y subjetividades. Literatura brasileña contemporânea, Rosário, Beatriz Viterbo Ed..

GULLAR, Ferreira (2007), Experiência neoconcreta, São Paulo, Cosacnaify. . (2006), Toda poesia, Rio de Janeiro, José Olympio.

MALUFE, Annita Costa (2006), Territórios dispersos: a poética de Ana Cristina Cesar. São Paulo, Annablume.

MESCHONNIC, Henri (2006), "A oralidade, poética da voz" [1987], Linguagem, ritmo e vida (trad. Cristiano Florentino). Belo Horizonte: FALE/UFMG.

OITICICA, Helio (1986), Aspiro ao grande labirinto, orgs. Waly Salomão, Luciano Figueiredo e Lygia Pape, Rio de Janeiro, Ed. Rocco.

PEDROSA, Célia (2006), "O olhar eloqüente", Poesia sempre, n. 22, Rio de Janeiro, Biblioteca Nacional.

PEDROSA, Mario (1965), "Arte ambiental, arte pós-moderna”, republicado in Oiticica, Helio (1986), opus citatum.

SUSSEKIND, Flora (2007), "Coro, contrários, massa: a experiência tropicalista e o Brasil de fins dos anos 60", in Basualdo, Carlos (org.) Tropicália, uma revolução na cultura brasileira, 1967-1972, São Paulo, Cosacnaify.

TASSINARI, Alberto (2001), O espaço moderno, São Paulo, Cosacnaify.

ZÍLIO, Carlos (1982) "Da Antropofagia à Tropicália" in Novaes, Adauto (org.) O nacional e o popular na cultura brasileira, São Paulo, Ed. Brasiliense.

ZULAR, Roberto (2005), “O que fazer com o que fazer? Algumas questões sobre o Me segura qu'eu vou dar um troço de Waly Salomão”, Revista Literatura e Sociedade, n. 8, São Paulo, DTLLC/USP e Ed. Nankin.

Obs.: Não foram incluídos nesta Bibliografia os artigos de jornal nem revistas de época citados no corpo do texto. 